\title{
MEDIA SOSIAL DAN PESAN POLITIK \\ (PERSEPSI PEMILIH PEMULA DALAM MENERIMA PESAN POLITIK PADA PEMILIHAN UMUM 2019 MELALUI MEDIA SOSIAL)
}

\author{
Herning Suryo, Haryo Kusumo Aji \\ Program Studi Ilmu Komunikasi \\ Universitas Slamet Riyadi Surakarta
}

\begin{abstract}
ABSTRAK
Di era revolusi industri 4.0 ini, teknologi menjadi hal yang utama untuk menunjang segala aspek, salah satunya di dalam peran media. Anak muda atau generasi milenial dan generasi $\mathrm{Z}$ sebagai pengguna terbanyak internet mempunyai kecenderungan menyebarkan pengaruh mereka kepada sesama pengguna media sosial dalam partisipasi politiknya. Anak muda sebagai netizen yang paling banyak mempunyai kecenderungan memberikan pengaruh ke sesama pengguna media sosial dalam partisipasi politiknya.

Patisipasi politik anak muda masa kini lebih terbuka dan dipengaruhi oleh media sosial yang mereka gunakan. Salah satu sebabnya karena intensitas yang besar dalam menggunakan media sosial. Tanpa disadari, sebagian besar kaum muda sudah membicarakan hal-hal yang berkaitan dengan politik sehingga membuat mereka ingin mengetahui perkembangan politik terkini.Oleh karena itu peneliti melihat bagaimana persepsi pemilih pemula, yang dalam hal ini adalah siswa dan mahasiswa saat menerima pesan politik pemilihan umum 2019 di dalam media sosial. Mengapa subyek yang diteliti adalah siswa dan mahasiswa karena generasi ini tidak tidak lepas dalam menggunakan media sosial untuk kesehariannya, baik itu untuk urusan pribadi maupun untuk mencari preferensi politik.

Para pemilih pemula ternyata menggunakan media sosial sebagai preferensi untuk memilih dalam pilkada dan pilpres oleh karena aktifitas yang banyak dihabiskan disana. Namun situasi politik yang memanas juga mempengaruhi konten di media sosial yang diakses oleh pemilih pemula, sehingga banyak yang merasa terganggu. Ada pula yang dapat memfilter informasi yang muncul di media sosial sehingga suasana menjadi lebih kondusif.
\end{abstract}

Kata Kunci : Persepsi, Media Sosial, Pemilih Pemula, Pesan Politik

\section{A. PENDAHULUAN}

Di era revolusi industri 4.0 ini, teknologi menjadi hal yang utama untuk menunjang segala aspek, salah satunya di dalam peran media. Teknologi memunculkan media baru (new media) sekaligus memungkinkan terjadinya konvergensi media, dimana melalui satu media dapat diperoleh beragam tampilan presentasi yang menarik untuk disaksikan. Konvergensi media menggabungkan unsur audio, visual, animasi, grafik, menjadi satu kesatuan yang dapat pula digunakan untuk menyampaikan pesan dalam proses komunikasi. Media baru ini memiliki ciri utama seperti kesalingterhubungan, aksesnya terhadap khalayak individu sebagai penerima atau pengirim pesan, interaktivitasnya, kegunaannya yang beragam sebagai karakter yang terbuka, dan sifatnya yang ada "dimana-mana" (delocatedness) (McQuail, 2011: 43).

Ketika perkembangan teknologi semakin cepat dan pesat, terutama di bidang teknologi informasi berbasis internet maka peran media komununikasi semakin penting. Oleh karena itu, sekarang media telah menjadi salah satu kebutuhan utama bagi setiap orang, terutama media yang menghubungkan orang-orang. Hal ini seiring dengan ditemukannya perangkatperangkat media yang berbasis internet, 
sehingga informasi menjadi sesuatu yang mudah ditemukan dibelahan dunia ini, dengan mengakses melalui internet mengenai informasi, hiburan, pendidikan, politik, ekonomi dan lain-lain.

Oleh karena itu, berdasarkan fenomena yang terjadi tersebut, komunikasi yang pada awalnya hanya sebatas proses interaksi personal secara face to face, kini berkembang secara online berbasis internet. Dalam hal ini, salah satu komunikasi berbasis internet yang banyak digunakan adalah media sosial. Media sosial adalah sebuah media online. Dengan hadirnya media berbasis internet (media online) tersebut menunjukkan telah terjadi pergeseran arah penggunaan media komunikasi, yang semula bersifat klasik (media elektronik dan cetak) dan kini mengalami perubahan kepada media baru (new media) berbasis internet yang menjadi saluran akses media sosial dalam berbagai bidang, yaitu pendidikan, budaya, sosial, ekonomi, hukum, juga politik, misalnya digunakan di dalam kampanye pemilu untuk mensosialisaikan visi, misi, dan program kerja seorang kandidat kepala daerah misalnya.

Anak muda atau generasi milenial dan generasi $\mathrm{Z}$ sebagai pengguna terbanyak internet mempunyai kecenderungan menyebarkan pengaruh mereka kepada sesama pengguna media sosial dalam partisipasi politiknya. Anak muda sebagai netizen yang paling banyak mempunyai kecenderungan memberikan pengaruh ke sesama pengguna media sosial dalam partisipasi politiknya.

$$
\text { Penggunaan sosial media }
$$

berkembang pesat seiring dengan semakin berkembangnya masyarakat pengguna pada tekhnologi komunikasi. Jumlah dan jenis media sosial ini sebagai fasilitas komunikasi yang dapat digunakan remaja dengan basis internet rumahan/sewa, smartphone, Tablet, dan lain sebagainya. Remaja sekarang tidak lepas dari sosial media yang digunakan untuk berbagai kebutuhan.

Patisipasi politik anak muda masa kini lebih terbuka dan dipengaruhi oleh media sosial yang mereka gunakan. Salah satu sebabnya karena intensitas yang besar dalam menggunakan media sosial. Tanpa disadari, sebagian besar kaum muda sudah membicarakan hal-hal yang berkaitan dengan politik sehingga membuat mereka ingin mengetahui perkembangan politik terkini.

Namun meskipun demikian, di lapangan tak dapat dipungkiri ditemukan sebagian dari anak muda sekarang skeptis terhadap politik. Alasannya bermacammacam, mulai dari sekedar malas, tidak peduli dengan politik, sampai mereka yang skeptis dengan politik dan pemilu. Sehingga tak heran jika banyak kaum muda yang memilih untuk menjadi golput pada pemilu

Oleh karena itu peneliti hendak melihat bagaimana persepsi pemilih 
pemula, yang dalam hal ini adalah siswa dan mahasiswa saat menerima pesan politik pemilihan umum 2019 di dalam media sosial. Mengapa subyek yang diteliti adalah siswa dan mahasiswa karena generasi ini tidak tidak lepas dalam menggunakan media sosial untuk kesehariannya, baik itu untuk urusan pribadi maupun untuk mencari preferensi politik. Mesin politik di partai pun menggunakan media sosial ini sebagai tempat untuk kampanye, karena menyadari bahwa ada sekitar 10 juta orang pemilih pemula, dimana suara ini sangat potensial untuk menaikkan elektabilitas calon dalam pemilu 2019. Media sosial dianggap juga sarana yang murah namun efektif karena dapat menjangkau banyak pemilih dalam waktu yang singkat.

Media sosial adalah sebuah media online yang menggunakan teknologi berbasis internet yang mendukung interaksi sosial, sehingga mengubah komunikasi menjadi dialog interaktif yang timbal balik. Dalam perkembangannya, media sosial menjadi penting sebagai sarana yang efektif dalam proses komunikasi politik, khususnya dalam konteks kampanye pemilu yang dapat menjadi perantara para politisi dengan konstituennya, yaitu antara komunikator dan komunikan secara jarak jauh dan bersifat massif. Oleh karena itu, melalui media sosial, komunikator dapat melakukan komunikasi politik dengan para pendukung atau konstiuennya, yaitu untuk membangun atau membentuk opini publik dan sekaligus memobilisasi dukungan politik secara masif.
Pemanfaatan media sosial juga telah meningkatkan jaringan komunikasi politik, relasi politik dan partisipasi politik masyarakat dalam pemilu. Hal ini sering kita jumpai dalam masa-masa kampanye politik para kandidat calon Kepala Daerah yang sedang maju dalam kompetisi pemilihan Kepala Daerah (Pilkada), maupun kandidat calon umum dalam Pilpres, dan dalam pemilihan anggota legislatif (Pileg).

Pemilih adalah warga Negara Indonesia yang telah genap berumur 17 tahun atau lebih atau sudah/pernah kawin(Pasal 1 ayat (22) UU No 10 tahun 2008 tentang Pemilu). Kemudian pemilih yang mempunyai hak memilih adalah warga Negara Indonesia yang didaftar oleh penyelenggara pemilu dalam daftar pemilih dan pada hari pemungutan suara telah genap berumur 17 (tujuh belas) tahun atau lebih atau sudah/pernah kawin. (Pasal 19 ayat 1 dan 2 UU No. 10 tahun 2008 tentang Pemilu).

Sementara itu, pemilih pemula adalah terdiri dari masyarakat yang telah memenuhi syarat untuk memilih, yang baru pertama kali melakukan penggunaan hak pilihnya. Mereka biasanya adalah pelajar berusia 17- 21 tahun, namun ada juga kalangan muda lainnya yang baru pertama kali akan menggunakan hak pilihnya dalam pemilu yakni para mahasiswa semester awal dan kelompok pemuda lainnya yang pada pemilu periode sebelumnya belum genap berusia 17 tahun (Modul 1 KPU, Pemilih Untuk Pemula. 2010: 48) 
Adapun syarat-syarat yang harus dimiliki seseorang untuk dapat menjadi pemilih adalah: 1. Warga Negara Indonesia yang berusia 17 tahun atau lebih atau sudah/ pernah kawin. 2. Tidak sedang terganggu jiwa/ingatannya 3 . Terdaftar sebagai pemilih 4.Bukan anggota TNI/Polri 5. Tidak sedang dicabut hak pilihnya 6.Terdaftar di Daftar Pemilih Tetap (DPT) 7.Khusus untuk Pemilukada calon pemilih harus berdomisili sekurang kurangnya 6 (enam) bulan di daerah yang bersangkutan (Sekretariat Jenderal KPU, 2010:1).

\section{B. METODE PENELITIAN}

Penelitian ini akan meneliti pemilih pemula yaitu siswa dan mahasiswa di Kota Solo yang menggunakan media sosial dalam mencari referensi politik untuk pemilihan umum. Untuk mengumpulkan data, maka metode perolehan data yang dilakukan adalah melalui dan wawancara. Wawancara berguna untuk mengungkap pengalaman, perasaan, tentang objek yang diteliti ketika menggunakan media sosial (Corbetta, 2003: 233). Teknik analisis data dilakukan sejak memulai wawancara sampai dengan diperolehnya data.

Interview (wawancara) merupakan alat pengumpulan data yang penting karena melibatkan manusia sebagai subjek sehubungan dengan realitas/ gejala yang diteliti. Kemudian wawancara yang dipakai menggunakan pedoman wawancara (interview guide) yang dimaksudkan untuk kepentingan wawancara yang lebih mendalam dan lebih memfokuskan pada persoalan yang menjadi pokok dari minat penelitian, yaitu melihat bagaimana media sosial dalam memberi pengaruh kepada pemilih pemula melalui pesan politik yang disampaikan.

Jenis penelitian ini adalah penelitian lapangan, dengan pendeketan metode studi kasus dimana metode ini cocok digunakan bila penelitian berkenaan dengan bagaimana dan mengapa. Yin (Yin, 2002:13) menyebutkan bahwa studi kasus sebagai sebuah bentuk penelitian yang mencoba menginvestigasi fenomena kontemporer dalam konteks kehidupan nyata terutama ketika batasan antara fenomena dan konteks tidak terlalu jelas.

Studi kasus bisa berarti metode atau strategi dalam penelitian, bisa juga berarti hasil dari suatu penelitian sebuah kasus tertentu. Studi kasus adalah suatu pendekatan untuk mempelajari, menerangkan, atau menginterpretasi suatu kasus dalam konteksnya secara natural tanpa adanya intervensi dari pihak luar (Salim, 2001:93).

\section{HASIL DAN PEMBAHASAN \\ 1. Motif}

Motif seseorang dalam melakukan sesuatu bisa berbagai hal, dan mungkin tidak sama antar individu walaupun kegiatan yang dilakukan sama. Motif seorang yang melakukan kejahatan di mata hukum dapat mempengaruhi vonis yang dijatuhkan. Bahkan motif ini dapat menjadi acuan seorang dalam memutuskan suatu perkara. 
Dalam penelitian ini salah satu variabelnya hendak mencari dan melihat apa motif pemilih pemula dalam menggunakan media sosial. Ketika seseorang yang dalam hal ini adalah pemilih pemula menggunakan media sosial dalam berekspresi ataupun aktualisasi diri maka ada motif yang melatarbelakanginya dan bisa bermacam-macam tergantung dari individu itu sendiri. Setelah dilakukan wawancara dengan narasumber yaitu seorang siswa dan mahasiswa sebagai pemilih pemula tentang apa motif ketika menggunakan media sosial untuk melihat pilihan politik, maka didapat hasil yang kurang lebih hampir sama. Berangkat dari rasa ingin tahu oleh perkembangan informasi yang terjadi di tengah masyarakat, khususnya tentang kandidat calon dalam pemilu. Kemudian informan juga menganggap bahwa dengan menggunakan media sosial dapat digunakan untuk mengetahui kejelasan atas informasi yang sudah ada, sehingga dengan demikian, informan yang sekaligus sebagai pemilih pemula dapat melakukan penilaian atas kandidat calon legislatif maupun calon Presiden.

\section{Faktor Eksternal}

Adanya faktor lain di luar motif dari dalam diri seseorang dapat juga mempengaruhi atau menarik minat seseorang dalam menggunakan media sosial. Faktor eksternal bisa bermacammacam bisa berupa interaktivitas, portabilitas, shareable, dll. Faktor eksternal ini bisa memungkinkan seseorang memiliki ketertarikan untuk menggunakan media sosial lebih besar daripada faktor internal itu sendiri, karena begitu banyak dan menariknya tampilan dan kegunaan yang bisa terwujud dari media sosial ini, sehingga kebutuhan itu bisa diciptakan.

Dalam wawancara oleh pemilih pemula, informan berpendapat bahwa menggunakan media sosial memang sesuatu yang memudahkan masyarakat dalam mencari kejelasan fakta mengenai calon pemimpin. Mudahnya akses yang disediakan situs ini menjadi daya tarik tersendiri sehingga masyarakat tidak memerlukan effort besar dalam mencari sebuah informasi. Tersedianya aplikasi khusus yang terbenam dalam gawai yang dimiliki oleh masyarakat menjadikan situs ini lebih mudah lagi untuk diakses dan dijangkau. Kemudian adanya fitur untuk membagikan atau share ke beberapa platform menjadi daya tarik tersendiri juga karena memenuhi salah satu kebutuhan manusia sebagai makhluk sosial untuk membagikan informasi kepada orang lain. Adanya fitur share ini menjadikan masyarakat dapat membagikan informasi yang sudah diperoleh kepada masyarakat lain sehingga fakta menjadi lebih jelas. Fakta tentang salah satu kandidat calon dapat dengan mudah didapat dan dibagikan kepada pengguna media sosial yang lain.

\section{Nilai-Nilai yang dianut}

Seseorang yang menggunakan media sosial dalam mengakses informasi pasti memiliki latar belakang yang beraneka ragam. Latar belakang seseorang sedikit banyak akan mempengaruhi nilai apa yang dianut selama ini, karena apa yang 
dianggap penting, benar, salah tergantung dari apa yang sudah dialami selama ini, termasuk lingkungan tempatnya berada. Penilaian tentang pasangan calon dalam pemilu juga berbeda-beda antar individu. Bagaimana pasangan dalam pemilu memperlihatkan dirinya di media sosial akan menentukan tanggapan dari pemilih pemula, misal latar belakang dari kehidupan pasangan calon dalam pemilu tersebut.

Informan yang dalam hal ini adalah pemilih pemula memang memiliki maksud ketika menggunakan media sosial, yaitu salah satunya menambah pengetahuan tentang latar belakang pasangan calon dalam pemilu. Hal ini yang menjadi nilai kegunaan yang dicari, yaitu pengetahuan dan informasi. Disamping itu juga dalam mencari nilai kepuasan, informan menggunakan media ini untuk sarana hiburan karena banyak segi hiburan yang ditawarkan oleh platform ini.

Kemudian ketika menyikapi adanya postingan dan tanggapan di media sosial yang dianggap meresahkan masyarakat, misal banyaknya bully dan saling hujat di antara pendukung pasangan calon, nilai kebaikan ini dibutuhkan. Ketika ada tanggapan positif dan membangun yang beredar, maka informan melakukan hal supaya tayangan tersebut beredar luas dengan menshare nya ke beberapa media sosial, kemudian memutus rantai share ketika menjumpai tanggapan negatif dan saling serang kehidupan pribadi, dan bukan visi misinya.

\section{Pengalaman}

Dalam variabel pengalaman ini hendak melihat hal yang sudah dilalui atau dilaksanakan oleh seseorang. Pengalaman dan pembelajaran kejadian serupa di masa lalu individu menjadi hal yang mendasari seseorang menginterpretasi suatu kejadian tertentu.

Informan yang ditunjuk dalam penelitian ini memiliki latar belakang sebagai pemilih pemula dimana baru sekali menggunakan hak pilihnya di dalam pemilu, oleh karena itu belum banyak pengalaman yang diperoleh dalam melakukan pemilihan umum. Informan membaca dan melihat jalannya pemilu sampai saat ini melalui media sosial, dimana mayoritas menggunakan instagram sekalipun masih banyak menggunakan media sosial yang lain seperti facebook, whatsapp, twitter, line.

Menurut pengalaman yang diperoleh saat menggunakan media sosial dalam mencari informasi tentang pemilihan umum adalah merasakan situasi yang kurang kondusif dan cenderung ricuh, terutama saat pemilihan presiden. Lebih banyak perdebatan kusir yang lebih mengarah kepada saling serang pribadi membuat hubungan keluarga dan pertemanan di antara para pendukung menjadi retak oleh karena berbeda pendapat.

\section{Kebudayaan yang Dianut}

Latar belakang kebudayaan individu menjadi salah satu variabel yang menjadi tolok ukur seseorang dalam menilai pasangan calon dalam pemilu. Latar belakang kebudayaan bisa terdiri dari: kepercayaan dari seseorang dan 
pemahaman dari seseorang tentang sesuatu hal.

Dalam penelitian ini, informan yang merupakan pemilih pemula berasal dari latar belakang siswa dan mahasiswa, dengan latar belakang kepercayaan yang beragam yaitu dari latar belakang agama muslim dan kristiani. Perbedaan latar belakang tersebut sedikit banyak mempengaruhi interest dalam membaca dan memilih pemberitaan tentang pasangan calon. Ketika menyaksikan pemberitaan yang di share di media sosial yang berisi konten negatif serta menjelekkan pasangan lawan, informan cenderung tidak langsung mempercayainya namun mencari dari beberapa sumber. Latar belakang pelajar dan mahasiswa cenderung untuk kritis terhadap berbagai informasi yang diterima. Sudah banyak himbauan untuk mengkroscek setiap informasi yang memecah belah, karena biasanya berita tersebut adalah hoax yang dibuat oleh sekelompok orang dengan tujuan memecah belah persatuan bangsa. Namun ada pula informan yang cenderung pasif serta tidak peduli dengan perdebatan di media sosial tentang pasangan calon di pemilu, karena tidak ingin menambah suasana menjadi lebih panas.

\section{Expectation atau Pengharapan}

Pengharapan dari individu terhadap media sosial yang menampilkan pasangan calon menjadi salah satu variabel dalam melihat persepsi seseorang ketika menggunakan media sosial menjadi preferensi politik. Harapan ini dibentuk dari informasi yang sudah didapat dari variabel sebelumnya. Maraknya perbincangan negatif yang menimbulkan perpecahan karena saling serang antar pribadi pasangan calon yang dilakukan para pendukungnya serta banyak yang bermuatan SARA menimbulkan seorang individu, dalam hal ini informan memberikan harapan ke depan. Harapan ini tentu saja bertujuan agar para pendukung tidak menggunakan media sosial untuk penyerang secara personal dan menimbulkan kegaduhan, namun hanya mengkiritisi kebijakan dan bersikap dengan positif.

Harapan dari informan yang dalam hal ini adalah pemilih pemula supaya masyarakat Indonesia menggunakan media sosial dengan bijak serta tidak menimbulkan kegaduhan politik dengan menyebarkan memperbanyak berita hoax dan tidak benar. Hendaknya warganet dapat memfilter berita politik yang di share ke media sosial agar suasana tetap kondusif, dan selalu mencek setiap konten berita yang ditampilkan agar berita hoax tidak semakin tersebar. Sebaiknya pengguna media sosial menggunakan media ini untuk hal yang benar, yaitu mencari informasi, latar belakang dan visi misi dari pasangan calon lalu hanya mengkritisi visi misi jika tidak sesuai dan bukan kepada personal atau kehidupan pribadi.

\section{KESIMPULAN DAN SARAN}

Kesimpulan dari penelitian yang berjudul "Media Sosial Dan Pesan Politik (Persepsi Pemilih Pemula Dalam Menerima Pesan Politik Pada Pemilihan Umum 2019 Melalui Media Sosial)” ini 
adalah motif seseorang menggunakan media sosial untuk preferensi politik adalah untuk mengetahui kejelasan informasi dari pasangan calon dalam pemilu. Faktor eksternal yang membuat pemilih pemula menggunakan media sosial adalah karena di media ini dapat dengan muda membagikan informasi yang sudah diterima kepada orang lain, sehingga rekan atau teman hanya menerima pesan yang valid dan benar.

Pemilih pemula menggunakan media sosial karena fungsi kegunaan dari media sosial ini yang meski tampil dengan desain menarik namun tetap bisa menyampaikan informasi yang benar tentang pasangan calon. Informan yang berasal dari latar belakang siswa dan mahasiswa merupakan orang terdidik sehingga cenderung kritis terhadap informasi yang beredar di media massa, oleh karena itu akan mencek informasi yang muncul dari berbagai sumber, dan akan memutus rantai hoax serta menyebarkan berita yang benar tentang pasangan calon dalam pemilu.

Saran dari peneliti adalah sebaiknya setiap masyarakat untuk kritis terhadap semua yang diterima dan tidak menerima secara mentah-mentah tanpa dikrocek kebenarannya, terlebih informasi yang menyerang personal dari pasangan calon dalam pemilu apapun, sehingga generasi penerus yang menjadi pemilih pemula akan terus aktif mengambil peran dalam politik dan tidak abstain karena takut akan kondisi politik di Indonesia.

\section{DAFTAR PUSTAKA}

Abdullah, Rozali, Pelaksanaan Otonomi Luas dengan Pemilihan Kepala Daerah Secara Langsung, Jakarta: PT Raja Grafindo Persada, 2005.

Arifin, Anwar, Komunikasi Politik, Paradigma, Teori, Aplikasi, Strategi komunikasi Politik di Indonesia, Jakarta: Balai Pustaka, 2006.

Budiardjo, Miriam, Dasar-Dasar Ilmu Politik, Jakarta: Gramedia, 1991.

Cangara, Hafied, 2009, Komunikasi Poli tik;Konsep, Teori, dan strat e gi, Raja Grafindo Persada, Jakarta

leo Agustino, Pilkada dan Dinamika Politik Lokal, Yogyakarta: Pustaka Pelajar, Lexy J.

Moleong, Metodologi Penelitian Kualitatif, Bandung: Remaja Karya. 2009

Nimmo, Dan, Komunikasi Politik, omunikator, Pesan, dan Media, Bandung: PT Remaja Rosdakarya, 2004.

Pawito, 2009, Komunikasi Politik: Me dia massa dan Kampanye Pemilihan, Kalasutra, Yogyakarta.

Rauf, Maswadi dkk, Indonesia dan Komunikasi Politik, Jakarta: PT Gramedia Pustaka Utama, 1993.

Saepul Muhtadi, Asep, Komunikasi Politik Indonesia, Dinamika Islam Politik Pasca Orde Baru,Bandung: PT Remaja Rosdakarya, 2008

Sugiono, Memahami Penelitian Kualitatif, Bandung: ALFABETA, 2005.

Sumarno, Dimensi-Dimensi Komunikasi Politik, Bandung: PT Citra Adtya Bakti.

Sutopo, H.B., 2006, Metodologi Peneliti an Kualitatif, UNS Press, Surakarta. 